\title{
DIAGNOSTIC SYSTEM OF DERMATITIS BASED ON FUZZY LOGIC USING MATLAB 7.0
}

\author{
Eneng Tita Tosida ${ }^{1}$ \\ Sri Setyaningsih ${ }^{2}$ \\ Agus Sunarya ${ }^{3}$ \\ E-mail: ttosida@yahoo.com,nuning@gmail.com,agusunarya@gmail.com.
}

Diterima :14 Juli 2010/Disetujui :23 Juli 2010

\begin{abstract}
This paper describes a fuzzy approach to computer-aided medical diagnosis in a clinical context for dermatitis. This research will use Mamdani fuzzy inference system for determining Dermatitis risk level. The Diagnostic system of Dermatitis based on Fuzzy logic are constructed with seven indication variables. These variables have different intervals and used for determining status of domains in membership function of variables. Knowledge base in this system is constructed by production rules (IF-THEN). Fire Strength are obtained in each fuzzy rules base for each type of Dermatitis, then composite by using Max-Min method. The final result is an output namely the risk Dermatitis level.
\end{abstract}

Keywords: Dermatitis, fuzzy logic, domain, membership function, fuzzy rule base.

\section{INTRODUCTION}

In disease diagnostic, paramedics often seem to be doubt full since some diseases have almost same indication. Therefore Fuzzy logic model is needed to solve the problem. Fuzzy logic is a form of logic which faced with half of true concept with the set of membership values between 0 and 1 . The development of theories shows that fuzzy logic can be used to model any systems including Dermatitis diagnostic.

1. Dosen Program Studi Ilmu Komputer Universitas Pakuan Jl. Pakuan, Bogor 16143 Jawa Barat, Indonesia

2. Dosen Program Studi Ilmu Komputer Universitas Pakuan J1. Pakuan, Bogor 16143 Jawa Barat, Indonesia

3. Dosen Program Studi Ilmu Komputer Universitas Pakuan J1. Pakuan, Bogor 16143 Jawa Barat, Indonesia 
According to Kusumadewi (2007), diagnosis of disease problems are often found and becoming a dominance on the Clinical Decision Support System(CDSS). In the common expert systems, diagnosis of disease problems have been developed widely. Software that has been built for the purpose of the oldest CDSS is MYCIN. MYCIN contains a number of rules, which is derived by the collaboration of experts. MYCIN use certainty factors (CF) to overcome the problem of uncertainty. Further software that has been developed is the QMR (1985), Dxplain (1986), and Iliad (1987) (Eneida A. Mendonça, 2004). ISABEL is a form of CDSS which is integrated with the Internet and provides several features for diagnosis. ISABEL was first built in 2001 and it is still being developed until now (Ramnarayan, et al., 2004). Some research example on disease diagnosis using fuzzy logic is the risk level classification of epilepsy (Harikumar R, Narayanan and Sabarish B, 2003, in Kusumadewi, 2007);

The crisp input data are converted into fuzzy data by fuzzy membership function through fuzzyfication, on contrary output convertion which is called the defuzzyfication process will result the diagnostic of Dermatitis. This research is implemented with MATLAB 7.0 programmable language that is fulfilled with fuzzy logic toolbox which form fuzzy inference system (FIS). However, in order to make user interaction with the system much more convenience, Graphic User Interface (GUI) is built using

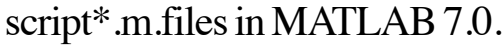

The objective of this research is implementing fuzzy inference system by using Mamdani method to determine Dermatitis risk level which suffered by patient who have symptoms clinical selection.

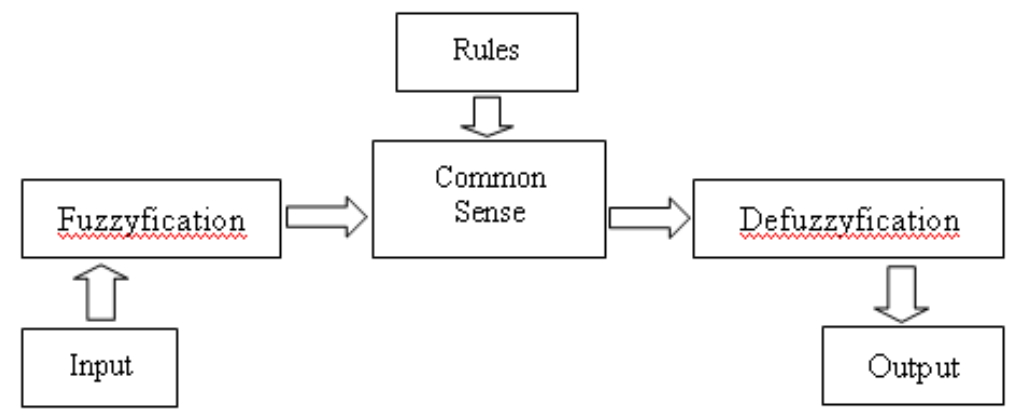

Figure 1. FIS Process

To get the output, four needed steps (Kusumadewi, 2004) are :

1). The Formation of Fuzzy Set 
In Mamdani method, both input variables and output variable are taken and divided into one or more set of fuzzy.

2). Implication of Membership Function Aplication (Production Rules);

Implication function which is used in Mamdani method is the Min rules.

3). Rules Component;

At this stage the system consists of several rules, the inference is obtained from the collection and correlation between the rules. There are three methods used in doing fuzzy inference system, that is Max, Additive and Probability (OR).

Max method, fuzzy association solution obtained by taking the maximum value of the rules, and implicating the state to output by using OR operator (union). In general it the can be written as :

$$
\mu_{\mathrm{df}}(\mathrm{x}-\mathrm{i}) \quad \max \left(\mu_{\mathrm{df}}\left(\mathrm{x}_{\mathrm{i}},\right) \mu_{\mathrm{kf}}\left(\mathrm{x}_{-}{ }_{\mathrm{i}}\right)\right) \ldots \ldots
$$

4). Defuzzyfication;

Input from the defuzzyfication process is a fuzzy set of the composition of the fuzzy rules, while the output produced is a set of numbers in the fuzzi domain. If a fuzzy set in a certain range are given, a crisp value should be taken as an output. Mamdani Deffuzification for the diskret universe can be written as

$$
\mathrm{z}={ }^{\prime} \mathrm{z}_{\mathrm{j}} \mu\left(\mathrm{z}_{\mathrm{j}}\right) / ” \mu\left(\mathrm{z}_{\mathrm{j}}\right)
$$

\section{RESULT AND DISCUSSION}

\section{A. Problem Analyzing}

Diagnostic of Dermatitis are created based on physical indication examination and patient medical complaint which is then defined as fuzzy variable. These indication variables includes itchiness, redness, swelling, skin scab, skin scale, skin blist and skin rash. For determining domain of fuzzy association, direct interviews to the expert were used. 
Tables 1. The Fuzzy variables

\begin{tabular}{|c|l|c|c|l|}
\hline Function & \multicolumn{1}{|c|}{$\begin{array}{c}\text { Variahle } \\
\text { Name }\end{array}$} & $\begin{array}{c}\text { Whole of } \\
\text { State }\end{array}$ & Unit & Remauts \\
\hline Ingut & itchiness & {$[0,100]$} & $\%$ & $\begin{array}{l}\text { Medical } \\
\text { patient } \\
\text { indication }\end{array}$ \\
\hline & redness & {$[0,100]$} & $\%$ & $\begin{array}{l}\text { Physical } \\
\text { indication }\end{array}$ \\
\hline & swelling & {$[0,100]$} & $\%$ & $\begin{array}{l}\text { Physical } \\
\text { indication }\end{array}$ \\
\hline & skin scab & {$[0,100]$} & $\%$ & $\begin{array}{l}\text { Physical } \\
\text { indication }\end{array}$ \\
\hline & skin scale & {$[0,100]$} & $\%$ & $\begin{array}{l}\text { Physical } \\
\text { indication }\end{array}$ \\
\hline & skinblist & {$[0,100]$} & $\%$ & $\begin{array}{l}\text { Physical } \\
\text { indication }\end{array}$ \\
\hline & skin rash & {$[0,100]$} & $\%$ & $\begin{array}{l}\text { Physical } \\
\text { indication }\end{array}$ \\
\hline Output & desease & {$[1,7]$} & - & Dematitis \\
\hline
\end{tabular}

\section{B. Forming Fuzzy Association And System Input-Output Variable} Membership Function

Function model for start and end the fuzzy region variables is shoulder-form curve, while triangle curve is used for crossing (Kusumadewi, 2004). The formulas for that representation are shown below :

$$
\begin{aligned}
& \mu[\mathrm{x}]=\left\{\begin{array}{ll}
1 & \{\mathrm{c} \leq \mathrm{a} \\
(\mathrm{c}-\mathrm{x}) /(\mathrm{c}-\mathrm{a}) & ; \mathrm{a} \leq \mathrm{x} \leq \mathrm{c} \\
0 & ; \mathrm{x} \geq \mathrm{c}
\end{array} \quad \mu[\mathrm{x}]= \begin{cases}0 & ; \mathrm{x} \leq \mathrm{e} \\
(\mathrm{x}-\mathrm{e}) /(\mathrm{g}-\mathrm{e}) & ; \mathrm{e} \leq \mathrm{x} \leq \mathrm{g} \\
1 & ; \mathrm{d} \geq \mathrm{g}\end{cases} \right. \\
& \mu[\mathrm{x}]=\quad \mu[\mathrm{x}]=
\end{aligned}
$$

Shoulder-form curve's formula (start and the end) ....(3)

$$
\mu[\mathrm{x}]= \begin{cases}0 & ; \mathrm{x} \leq \mathrm{b} \text { atau } \mathrm{x} \geq \mathrm{f} \\ (\mathrm{c}-\mathrm{x}) /(\mathrm{c}-\mathrm{a}) & ; \mathrm{b} \leq \mathrm{x} \leq \mathrm{d} \\ (\mathrm{d}-\mathrm{x}) /(\mathrm{f}-\mathrm{d}) & ; \mathrm{d} \leq \mathrm{x} \leq \mathrm{f}\end{cases}
$$

Triangle curve's formula..........(4) 
Based on those rules that are developed by formula (3) and (4), we can obtain the linguistic expression for input or output variables. For example forming membership function for the input variable itchiness was designed by formulas that shown below. These (formulas) are obtained based on expert/specialist medical's input. Membership function of whole itchiness input variables defined as :

$$
\begin{aligned}
& \mu \text { Very light }[\mathrm{x}]= \begin{cases}1 & ; \mathrm{x} \leq 10 \\
(30-\mathrm{x}) / 20 & ; 10 \leq \mathrm{x} \leq 30 \\
0 & ; \mathrm{x} \geq 30\end{cases} \\
& \mu \text { Light }[\mathrm{x}]= \begin{cases}0 & ; \mathrm{x} \leq 10 \text { or } \mathrm{x} \geq 50 \\
(\mathrm{x}-10) / 20 & ; 10 \leq \mathrm{x} \leq 30 \\
(50-\mathrm{x}) / 20 & ; 30 \leq \mathrm{x} \leq 50\end{cases} \\
& \mu \text { Cronic }[\mathrm{x}]= \begin{cases}0 & ; \mathrm{x} \leq 75 \\
(\mathrm{x}-75) / 15 & ; 75 \leq \mathrm{x} \leq 90 \\
(1 & ; \mathrm{x} \geq 90\end{cases}
\end{aligned}
$$

The membership function for input variable itchiness is shown completely in Figure 2. Verylight Light Medum Heary Cronic

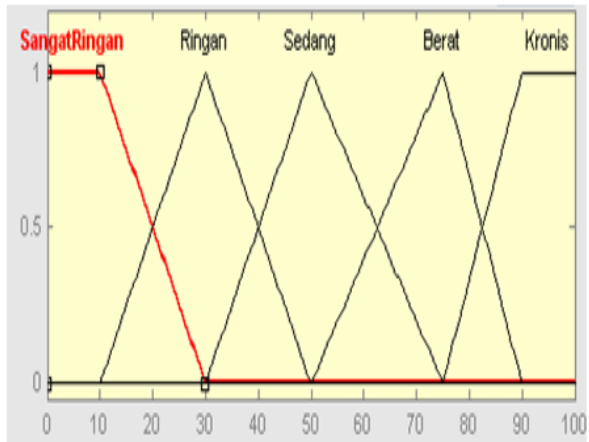

Figure 2. Itchiness membership function

Then we can obtain domain of any fuzzy associations which had been formed and shown in Tables 2 . This process is called the fuzzyfication process. 
Tables 2. Fuzzy Association

\begin{tabular}{|c|c|c|c|}
\hline Tariable & 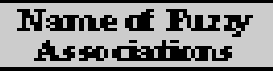 & Domaīi & LFūit \\
\hline \multirow{5}{*}{ Irtious } & Wery lizit & $0 ; 10 ; 30 ;$ & \multirow{5}{*}{$\vartheta$} \\
\hline & Li新立 & $10 ; 30 ; 50$ & \\
\hline & Intedinm & $30 ; 50 ; 75$ & \\
\hline & Henny & $50 ; 7590$ & \\
\hline & Expritic & $75 ; 90 ; 100$ & \\
\hline \multirow{5}{*}{ Funtues: } & Wory li $=\xi t$ & $0 ; 30 ; 45$ & \multirow{5}{*}{$\nLeftarrow$} \\
\hline & Li; & $30 ; 45: 60$ & \\
\hline & Intedinm & $45 ; 60 ; 75$ & \\
\hline & Henmy & $60 ; 75 ; 90$ & \\
\hline & Frorit & $75: 90 ; 100$ & \\
\hline \multirow{5}{*}{ Swrellifig. } & Tory lig $=7 t$ & $0 ; 10 ; 25 ;$ & \multirow{5}{*}{$\%$} \\
\hline & Li $=\neq 1$ & $10 ; 25 ; 45$ & \\
\hline & It[edinm & $25 ; 45 ; 65$ & \\
\hline & Heany & $45: 65: 80$ & \\
\hline & Croria & $65 ; 80 ; 100$ & \\
\hline \multirow{5}{*}{ Shirl scab } & Tory lickt & $0 ; 10 ; 30$ & \multirow{5}{*}{$\psi$} \\
\hline & Li新立 & $10 ; 30 ; 50$ & \\
\hline & Intedinm & $30 ; 50 ; 70$ & \\
\hline & Henmy & $50 ; 70 ; 90$ & \\
\hline & Fopic & $70 ; 90 ; 100$ & \\
\hline \multirow{5}{*}{ Bh:irt scale } & Wors liz;t & $0_{i} 2 \pi_{i} 4 s_{i}$ & \multirow{5}{*}{$\vartheta$} \\
\hline & Li体往 & $20 ; 45 ; 60 ;$ & \\
\hline & IttedinIm & $45 ; 60 ; 75$ & \\
\hline & Hendy & $60 ; 75: 90$ & \\
\hline & Esprix & $75 ; 90 ; 100$ & \\
\hline \multirow{5}{*}{ shiriblit } & Tory lis $=7 t$ & $0 ; 10 ; 0$ & \multirow{5}{*}{$\%$} \\
\hline & Li隹圷 & $10 ; 20 ; 40$ & \\
\hline & Intedinm & $20 ; 40 ; 60$ & \\
\hline & Hendy & $40 ; 60 ; 70$ & \\
\hline & Drorit & $60 ; 70 ; 100$ & \\
\hline \multirow{5}{*}{ Bhiringati } & Tor li: & $0 ; 10 ; 25$ & \multirow{5}{*}{$\vartheta$} \\
\hline & Li; $\neq$ tut & $10 ; 25 ; 50$ & \\
\hline & Intedinm & $25 ; 50 ; 75$ & \\
\hline & Henory & $50 ; 75 ; 90$ & \\
\hline & Cromic & $75: 90 ; 100$ & \\
\hline \multirow{7}{*}{ Desense_DhtTIt } & $\begin{array}{l}\text { Stwis } \\
\text { Itritantis }\end{array}$ & $0 ; 125 ; 25$ & \multirow{7}{*}{ - } \\
\hline & $\begin{array}{l}\text { Serwe } \\
\text { Derpatitis }\end{array}$ & $125 ; 5 ; 35$ & \\
\hline & $\begin{array}{l}\text { Potopal } \\
\text { Dermatis }\end{array}$ & $25 ; 375 ; 5$ & \\
\hline & $\begin{array}{l}\text { Deprotr: } \\
\text { Derpantis }\end{array}$ & 37505050 & \\
\hline & 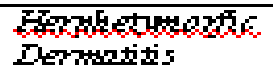 & $50 ; 625 ; 75$ & \\
\hline & $\begin{array}{l}\text { Atbopis } \\
\text { Dermatis }\end{array}$ & $625 ; 5 ; 875$ & \\
\hline & 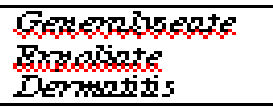 & $75: 87 ; 100$ & \\
\hline
\end{tabular}


The process which is held on whole membership function for input variables are designed in the same way. The Dermatitis membership function as an output variable is showed in Figures 3.

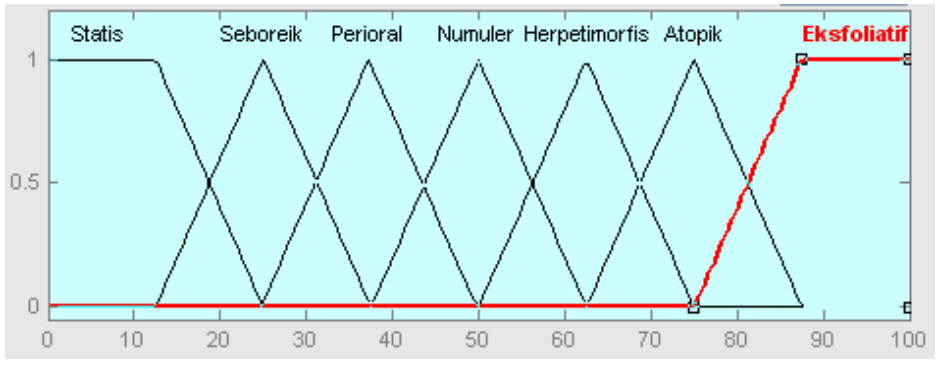

Figures 3. Dermatitis membership function

Membership function for disease output variables especially Static Dermatitis can be defined as :

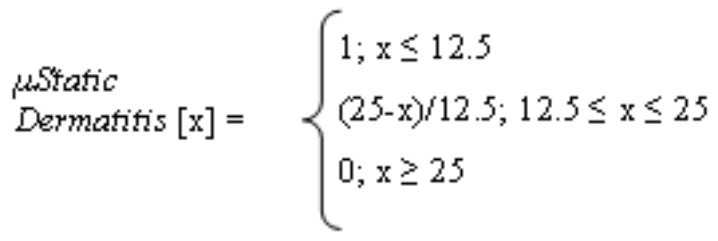

The same way are used to form others output variables. The whole design can be shown in figure 3 .

\section{Knowledge Base}

There are seven clinical symptoms which influence seven types of Dermatitis. Every rules consists of some antecedents. Therefore, every type Dermatitis have weight by every symptom through fire strenght which is passed to correspond rules. For the final result, the level of Dermatitis risk are calculated by using Max-Min method from each Dermatitis rules. The knowledge bases which show relation between symptoms with diseases are compiled by using Production Rules Methode IF-THEN, and it is shown in figure 4.

Based on modeling process and verification result of the expert/physician for Dermatitis diagnostic system, there were 193 fuzzy rules. 


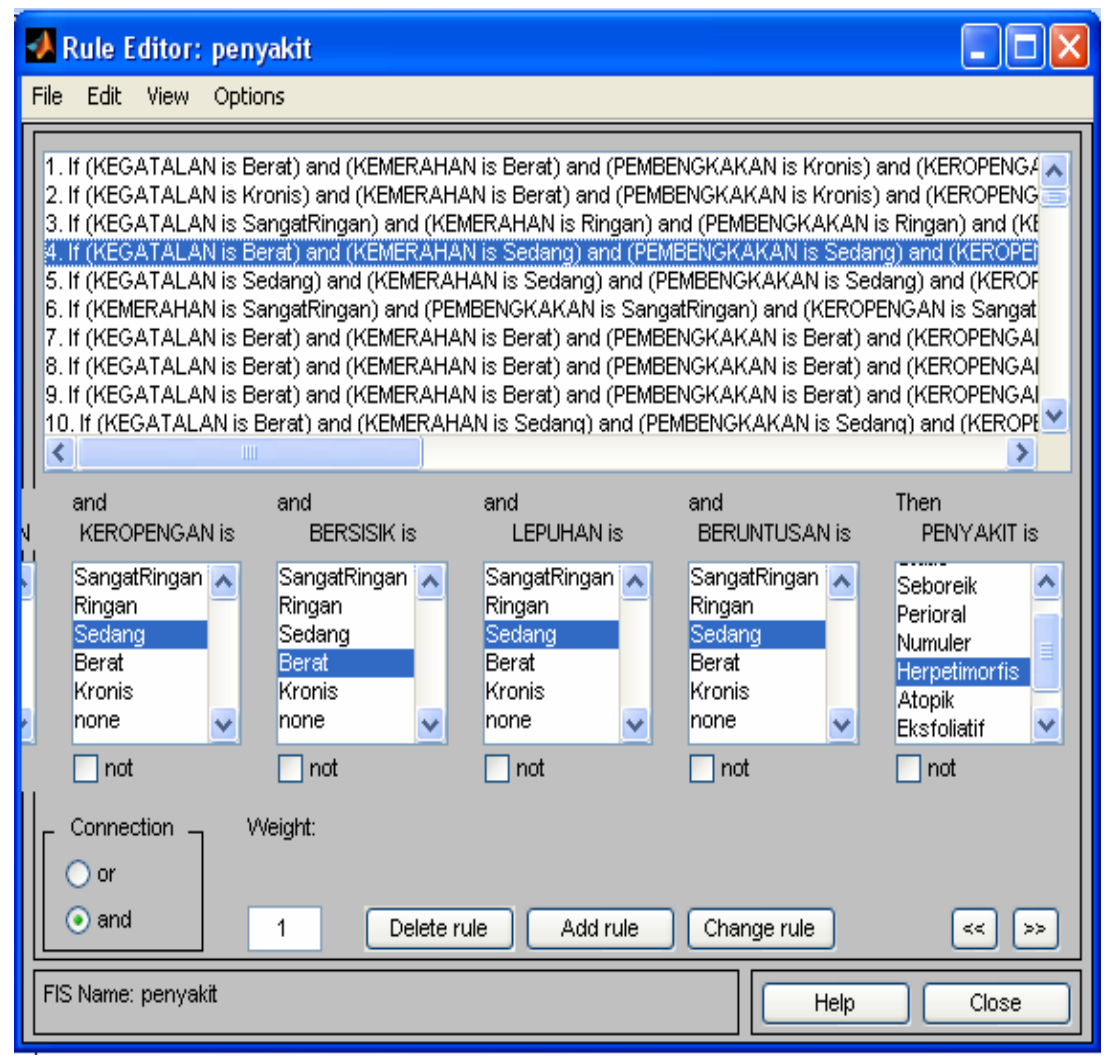

Figure 4. Fuzzy Rules Editor

The Defuzzification process in Mamdani rule composition has some defuzzyfication methods, one of them is the Centroid Method (Composite Moment). From this method, the output variables crisp are counted with finding value $\mathrm{z}^{*}$ (center of gravity) variables of its membership function.

$$
z^{*}=\frac{\int \mu_{\underline{c}}(z) \cdot z d z}{\int \mu_{\underline{c}}(z) d z}
$$

The risk level of Dermatitis is represented by percentage number, between $0 \%$ until $100 \%$. The more closely to $100 \%$, the higher risk level are shown.

\section{Design And System Implementation}

Flowchart of Dermatitis Diagnostic system based on Fuzzy logic is shown in Figures 5. 


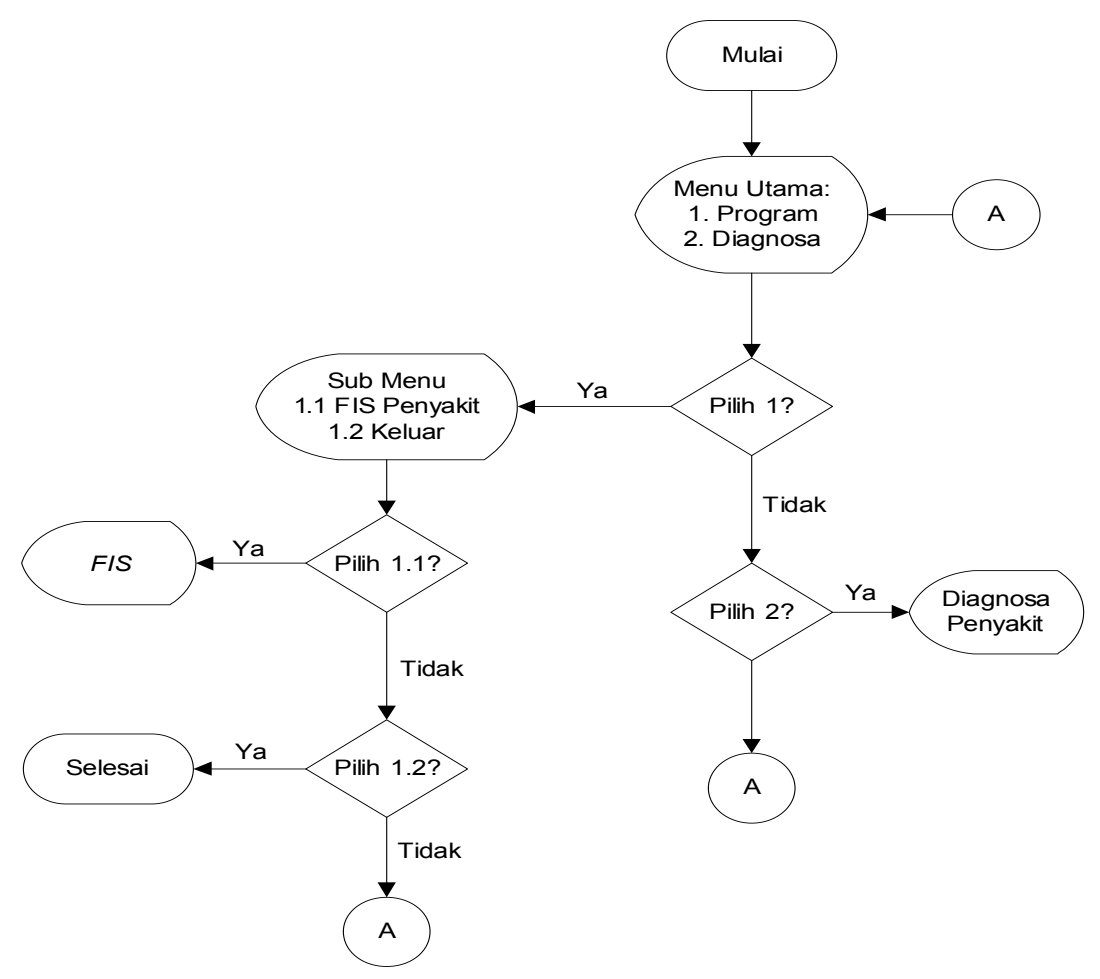

Figures 5. Flowchart of system

\section{E. Case}

A patient suffered symptoms such as : itchiness very light (17\%), Redness light (24\%), Swelling very light (15\%) Skin scab very ligtht (13\%), Skin scale light (25\%), Skin blist light (19\%) and Skin rashlight (21\%). After the inferences to each hypothesizing are done by using Mamdani method as referred to Figure 6, by the result of diagnostic, it can be seen that the patient has a $14.38 \%$ possibility of risk level of Dermatitis Statisis. On the other hand Dermatitis Statis was a kind disease of diagnostic result for this case. Besides that output, this system is also provided by the explanation of the diseases concerning with its cause and alternatives treatment to every type of Dermatitis. Illustration of this matter is showed inFigure 6. 


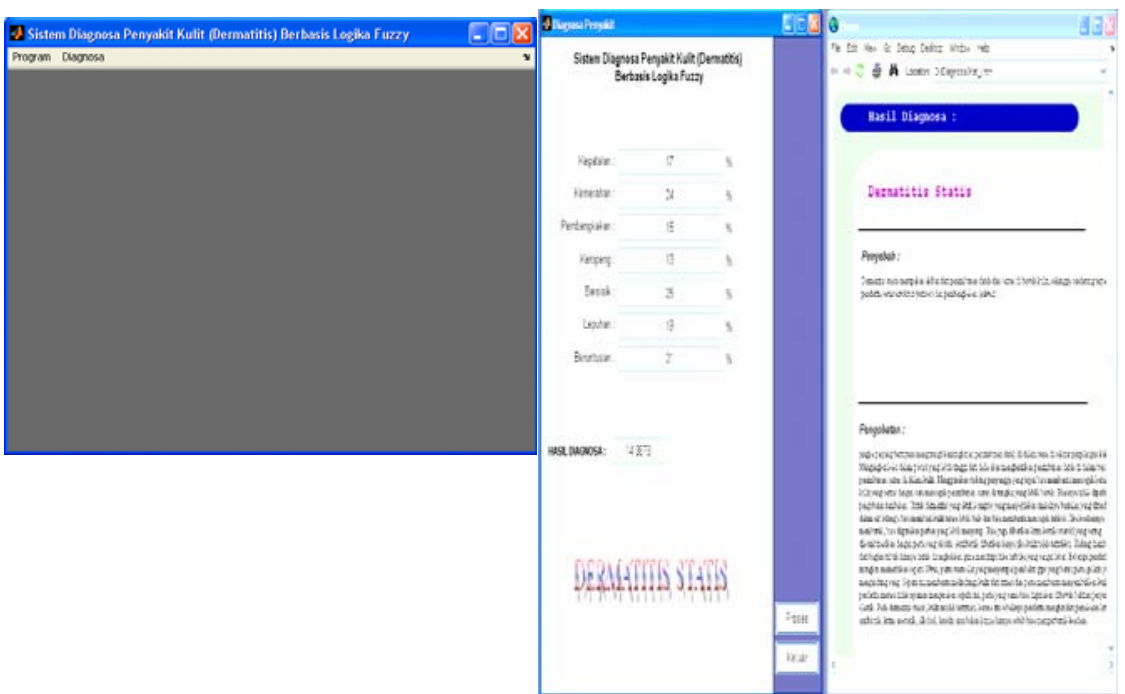

Figures 6. Main form, diagnostic process and output system

\section{F. Validation}

The further step is validation. The case in Figure 6 is used for validation process. The following case was compared by expert with output data program, then input membership degrees are found appropriate with the previous membership function. Value of fuzzy membership for itchiness variables at any associations are shown below:

Very light fuzzy

Found from

f[17]

Light fuzzy associ

[1] $=(1$

Medium fuzzy as

Heavy fuzzy asso Cronic fuzzy asso

The next step is s

Fuzzy interference process in this research used min-max rule, then it withdrawn the highest value from the result of the first count by using OR command, as shows above. Based on the result, it could be determined that the selected rule is rule no. 65 , therefore the diagnostic result is $14.38 \%$ which mean that the patients medically suffer Static Dermatitis. 


\section{CONCLUSION}

Dermatitis Diagnostic System based on fuzzy logic are constructed with seven variables, ie. Itchiness, redness, swelling, skin scab, skin scale, skin blist and skin rash. These variables had different intervals. The values are used to determine the domain status which is used in membership function of any variables. Domain classification were very light, light, medium, heavy, cronic. This classification are obtained from intuitive result and had been confirmed by the expert.

The Membership function that is built with fuzzy rule base, consist of 193 rules as part of Fuzzyfication input process. To facilitate interaction between user and system, MATLAB 7.0. is provided with GUI (Graphic User Interface). The output system consist of Dermatitis diagnostic, ie. Static Dermatitis (10-20\%), Seboreic Dermatitis (21-35\%), Perioral Dermatitis (36-45\%), Numular Dermatitis (46-65\%), Herphetymorfic Dermatitis (66-80\%), Athopic Dermatitis (81-90\%), and Generalyseate Expoliate Dermatitis (91-97\%). Fuzzificated output produce certain Dermatitis diagnostic.

One of the constraints of this research was determining fuzzy membership function in system building since there was not standard form which is yet released by the expert. Therefore the result obtained at real data examination are sometimes unappropriate with the ouput data program.

\section{E. REFERENCES}

[1] Abdurohman, A. Bab 2, http://www.geocities.com/arsiparsip/tatf/ tabab2.htm, 2001.

[2] Goebel, G, An Introduction To Fuzzy Control Systems, Public Domain. http://www.faqs.org/faqs/, 2003.

[3] Gunaidi, AA., The Shortcut MATLAB Programming, Informatika, Bandung, 2006.

[4] Kristanto, A., Kecerdasan Buatan, Graha Ilmu, Yogyakarta, 2004.

[5] Kusumadewi, S.,Analisis \& Desain Sistem Fuzzy Menggunakan Toolbox Matlab, Graha Ilmu, Yogyakarta, 2002.

[6] Kusumadewi, S \& Purnomo, H., Aplikasi Logika Fuzzy untuk pendukung keputusan, Graha Ilmu, Yogyakarta, 2004.

[7] Marimin, Teori dan Aplikasi sistem pakar dalam teknologi manajerial, IPB Press, Bogor, 2005.

[8] Panjaitan, L.W., Dasar-dasar Komputasi Cerdas, C.V ANDI OFFSET, Yogyakarta, 2007. 
[9] Piattini, Galindo \& Urrutia, Fuzzy Databases Modeling, Design and Implementation, Idea Group Publishing, London, 2007.

[10] Sugiharto,A.Pemrograman GUI (Graphic User Interface) dengan MATLAB, C.V ANDI OFFSET, Yogyakarta, 2006.

[11] Sumathi, Sivanandam \& Deepa, Introduction to Fuzzy Logic using MATLAB with 304 figure and 37 tables, Springer, Berlin, 2007.

[12] http://www.fuzzytech.com 25-Des-2007

[13] http://www.medicastore.com\medVkategori_pyk18e5.html 06 Juni 2007

[14] http://www.medicastore.com/medsubkategori pyk04f0.html? idktg $=14 \& \mathrm{UID}=20071118183038202.182 .51 .230$ 01-Januari-2008 